\title{
A LIFE HISTORY OF THE 'IRISH' ECOTYPE TIED STONES AND LOOSE DOGS
}

\author{
MARCAS MAC COINNIGH \\ Irish and Celtic Studies \\ School of Arts, English and Languages \\ Queen's University Belfast \\ University Road, BT7 1NN Belfast \\ Email: m.maccoinnigh@qub.ac.uk
}

\begin{abstract}
The term ecotype was first introduced to the field of folkloristics by Carl Wilhelm von Sydow (1878-1952), who proposed the idea that folktales develop from base forms due to transformations triggered by specific environmental conditions before eventually stabilising within cultural districts. The general analogy was popular amongst folklorists who readily invoked the concept to deconstruct a wide range of genres including rhyming couplets, folk ballads, folktales, fairytales, personal narratives, legends and urban legends. It is unfortunate, however, that ecotypes have largely been ignored by scholars working in the fields of paremiology, especially when one considers not only the established inter-relationships between proverbial material and other folkoristic genres, but also the recent pioneering cross-cultural analyses of idiomatic expressions in European languages and beyond.

This paper will provide a template for the analysis of folk expressions by examining the life history of an Irish ecotype, tied stones and loose dogs. It will show that folk expressions are a fertile area of research that can be deconstructed using literary and historical research based on the historic-geographic method. At the heart of this template, I argue, is the need to read texts within their contemporary cultural, historical and socio-economic frameworks to decode meanings according to instantiation, the motivations for their use, and the question of agency in folk groups. By collecting, examining and construing inter-relations between folkloristic texts across a range of cultural products - folklore collections, popular culture periodicals and political discourse - and by informed cultural contextualisation of its instantiations, we can re-construct the extensive cultural underpinnings that inform a range of everyday folk expressions.
\end{abstract}

KEYWORDS: ecotype $\bullet$ ecotypification $\bullet$ Irish language $\bullet$ jest-tale $\bullet$ “Tied Stones and Loose Dogs" 
The term ecotype ${ }^{1}$ was first introduced to the field of folkloristics by Carl Wilhelm von Sydow (1878-1952) in a Swedish language article titled "Om traditionspridning" (1932) and subsequently in "Geography and Folk-Tale Oicotypes" (1934). In an essentially Darwinian approach, von Sydow's (1934: 349) concept of oikotypification ${ }^{2}$ proposed the idea that folktales develop from base forms due to transformations triggered by specific environmental conditions, namely "time-depth, isolation, boundaries, migratory nature of materials, group disposition, and geographical experience" (Cochrane 1987: 35), and that by a process akin to natural selection, distinct, localised forms develop in isolation, before eventually stabilising within a particular cultural district. ${ }^{3}$ These changes are both organic, in that they develop as a natural response to environmental conditions, or what he termed cultural imperatives, and also intentional, in that alteration is driven by the performer's requirement to produce an acceptable, authentic item for consumption by her/his linguistic community. ${ }^{4}$ Alteration is typically observed in the content and style of the tale, he argued, and, as a result, a variant form emerges which is peculiar to that particular community. ${ }^{5}$ One of the most important aspects of ecotypes is that because they traverse international, national, and regional borders, they are often valuable barometers of the cultural preferences of folk groups within a defined geographical unit.

Whilst the general analogy was popular amongst folklorists, i.e. that folkloristic items, particularly narratives, adapt to their natural environment in the same manner as biological organisms, the fuzziness of applying biological metaphors to folkloristic material created grey areas over the central questions of definition and conditions of application. ${ }^{6}$ As a result, it was not uncommon for folklorists to place selective emphasis on elements that they themselves viewed to be important, for example geographical factors (Foster 1969), group ethos (Abrahams 1963; 1964), or structural changes (Dundes 1962). Developments soon followed. Scholars such as Richard Dorson (1956), John Wilson Foster (1969) and, to some extent, Alan Dundes (1962) argued, in line with von Sydow's (1948: 57) original thinking, that content and style and are the main narrative elements subject to change, although noting that context - often seen within a performative lens as audience belief and interest - is also reflected. Dundes (1962) developed this further and, from an essentially structuralist perspective based on Vladimir Propp's (1958) morphological approach, ${ }^{7}$ advanced that hypothesis that the presence of pre-existing structural forms within a particular culture increases the probability that foreign examples of the same type will be accepted and borrowed into that culture. Roger Abrahams' (1963: 99; 1964) eclectic analytical approach - blending comparatavist and anthropological methodologies - stressed the importance of documenting the full cultural context of folkloristic items. While advancing the idea that ecotypes can be extremely illuminating in demonstrating the ideas and beliefs of individual folk groups, he also made the plea for more comprehensive analyses of function (Abrahams 1963: 101). The concept was not accepted universally in the discipline, however, and there were those, such as Warren Roberts (1953) and Stith Thompson (1968: 370), who dismissed ecotypes as the "hypothetical constructs of scholars." At the heart of their argument was the claim that there is little difference between ecotypes and local sub- 
forms, although this largely ignores the influence of socio-cultural contexts or what von Sydow has termed "prevailing tastes." 8

Nevertheless in spite of such academic discord, a wide range of scholars have readily invoked the concept to deconstruct a range of folkloristic genres including rhyming couplets (Hopkin 2003), folksongs and folk ballads (Bošković-Stulli 1966; Cunningham 1976; Narváez 2002), folktales (Dundes 1962; Roberts 1966; Dégh 1972; Ballard 1983), fairy-tales (Dégh 1961), Wellerisms (Järviö-Nieminen 1959), personal narratives (Kalc®ik 1975), legends (Ellis 1983) and 'urban legends' ${ }^{\prime}$ (Brunvand 1974; Fine 1987; 1992; Goldstein 1996; Ashton 2001). ${ }^{10}$ In recent years, Galit Hasan-Rokem's (2000; 2003) innovative use of ecotypes to elicit 'the orality in the written' (Hasan-Rokem 2003: 2) in rabbinic literature has opened new perspectives on the interface of class, gender, culture, religion and ethnicity in Late Antiquity. Whilst there has also been a re-engagement with ecotypes in interdisciplinary studies, particularly in the social sciences (for example, Wolf 1966; Löfgren 1976; 1980; Hopkin 2003; 2016). Scholars such as David Hopkin (2016: 31, 36) have argued for using ecotypes as a means of bridging gaps between social history and cultural history, as ecotypes reveal not only the cultural preferences of the group but also connect those preferences to particular experiences.

In light of such analyses within the field of folkloristics and contemporary calls for resurrecting the concept in the social sciences, it seems unfortunate that ecotypes have largely been ignored by scholars working in the associated fields of paremiology and phraseology. While there are numerous excellent comprehensive studies of the history and development of individual proverbs and proverbial expressions (for example Kunstmann 1939; Friedman 1974; Mieder and Hand 1991; Mieder 1996), they do not deal with the ecotype per se. This is particularly surprising when one considers not only the established inter-relationships between proverbial material and other folkloristic genres, such as the fable, the folktale and the riddle, but more importantly, the recent pioneering cross-cultural analyses of Elisabeth Piirainen (2012; 2016a; 2016b) and Dmitrij Dobrovol'skij with Piirainen (2005) in tracing the development of idiomatic expressions in European languages and beyond.

\section{CLOCHA CEANGAILTE AGUS MADRAÍSCAOILTE'TIED STONES AND LOOSE DOGS': AIMS AND METHODOLOGY}

Whilst variation, distribution and dissemination, both in time and space, are key aspects of any general folkloristic analysis (Brunvand 1981: xii), the treatment of ecotypes to date has largely focused on the issue of structural change, often at the expense of other important issues, such as the motivations that generate such adaptions or how the attendant function has changed as a result of environmental circumstances. ${ }^{11}$ The ecotype, therefore, poses specific questions about how and why certain folk groups adopt and reformulate folkloristic texts, and moreover, the role of the immediate environment particularly, I would argue, the role of socio-economic and historical circumstances - in motivating these transformations. ${ }^{12}$

As a case study of ecotype development, this paper will examine the Irish-language expression clocha ceangailte agus madraí scaoilte 'tied stones and loose dogs', which is used 
as a synonym for a state of imbalance or inequality, as a core element of an ecotype. ${ }^{13}$ By core element, I understand this to mean the minimal remainder, or kernel, ${ }^{14}$ necessary for identifiable iteration of the ecotype. Through a textual genealogy based on the historic-geographic method, the paper will challenge the erroneous claim that this is "a phrase in ancient Irish that has a folktale behind it" (Higgins 2012) by outlining the history, dissemination and ecotypification of the expression in the Indo-European folk tradition since earliest times. It will detail the first attested use of the expression in the folktale On the Advantage of Silence, first recorded by the Persian poet Sa'di in his Gulistān or Rose Garden of 1258 (see Rehatsek 1964), before moving on to examine parallels in content, style and genre-blends in later texts. Sources will include instantiations in English language printed sources, namely popular publications containing examples of folklore, jest-books, newspapers and periodicals covering the 17th-19th centuries in Britain and North America, ${ }^{15}$ Irish folkloric sources of the 19th and 20th centuries and a late 20th-century legal precedent in the Irish court system.

My core argument is that by reading instantiations of the 'tied stones loose dogs' text within the context of contemporary cultural, historical and socio-economic frameworks, we can decipher the motivations that underpin its ecotypification. The overarching motivation in this particular example, I will contend, is socio-economic tension between centre and periphery, communicated along the lines of Edward Said's (1978) Othering in the form of institutionalised stereotypes and encoded in the tale narrative. The jest-tale in England in the 17th to 19th centuries reflects urban-rural tensions evident in the metropolis; while in the emergent USA it exposes a nascent native-immigrant hostility. Likewise, the appearance of the tale in Irish folkloristic sources of the 19th and 20th centuries is also motivated by socio-economic tensions but, as a result of localisation and the lack of external contact, the emphasis is primarily the mockery of place as opposed to the denigration of Other peoples. The final section will illustrate how this text has been appropriated by formal institutions for the establishment and validation of norms of cultural behaviour. In particular, I will show how the punchline 'tied stones and loose dogs' was extracted from the jest and codified in institutionalised form - as a synonym for a state of inequality and imbalance - in a legal precedent in 1971, namely Re Haughey [1971] IR 217, and subsequently perpetuated and embedded through a series of legal pronouncements as part of the Irish judicial canon. ${ }^{16}$

\section{THE GULISTA A N OF SA'DI}

The Gulistān, written in $1258^{17}$ by the famous Persian poet Sa'di, is a collection of didactic fables in rhymed prose arranged in eight distinct chapters according to subject matter. One of the most popular tales in the collection appears in chapter four entitled On the Advantage of Silence. ${ }^{18}$ The narrative tells how a poet recites a panegyric that displeases an amir of robbers and so he is stripped naked as punishment. When he is subsequently attacked by a pack of dogs, he attempts to defend himself only to discover that the stones are frozen to the ground. Surprised at this he responds "What whore-sons of men are these? They have let loose the dogs and have tied down the stones!" The amir finding humour in this poet's wit decides to reward the poet with his choice of gift, to 
which he eloquently requests the return of his robe. The amir takes pity on him, returns his robe and lets the poet on his way. ${ }^{19}$ The main points of the story may be organised according to William Labov and Joshua Waletzky's (1967: 12-44) theory of narrative analysis as follows: ${ }^{20}$

1. Orientation: poet's panegyric displeases an amir of robbers - poet is stripped naked as punishment.

2. Complication: dogs attack the poet - poet tries to defend himself but the stones are frozen to the ground - poet utters the expression "What whore-sons of men are these? They have let loose the dogs and have tied down the stones."

3. Evaluation: amir finds this comment humorous.

4. Resolution: poet eloquently utters a noble request.

5. Coda: amir takes pity on him and rewards the poet.

In line with the general message of Chapter 4 "On the Benefits of Silence", the tale functions as a loose warning against loquacity. It is the poet, as wordsmith par exellence, together with his penchant for the panegyric who causes the debacle and, although he is able to use his wit to extricate himself, the underlying message is that it is often more prudent to remain silent. The punchline is invoked by the humorous inversion of normality in the incongruous sentence "They have let loose the dogs and have tied down the stones!" For whilst loose dogs is a non-marked phrase that conjures up instinctive feelings of danger, threat, and fear, the phrase tied stones is an uncommon collocation without any clear functional purpose, i.e. there is no logical reason to tether an inanimate object. At best it is not entirely deviant but, at some level, non-felicitous. Yet, when these phrases are juxtaposed, it becomes clear that there is an illogical linkage between the elements: it is the norm for dogs to be tied, and stones to be loose. As we shall see later, this concatenation fits loosely with the concept of a bull, which may be defined as a manifestly self-contradictory or inconsistent statement that is typically unperceived to the speaker. ${ }^{21}$ Nevertheless, it is clear from the context that the inconsistency is not unnoticed by the poet and it is this recognition of the schema conflict that causes the amir to laugh. ${ }^{22}$

Sa'di frequently introduces his anecdotes as things he saw or heard about during his travels, ${ }^{23}$ and while some of these obviously draw upon literary tradition, Henri Massé (1919: 257-259) has shown that relatively few have been traced to specific written sources. Prof. Mahmoud Omidsalar believes that the 'tied stones and loose dogs' tale was most likely not an original composition of Sa'di's, but was either recorded from oral tradition or adapted from a literary source. ${ }^{24}$ Prof. Ulrich Marzolph has confirmed, however, that the tale is not found in any of the classical Persian literary texts nor is there any evidence in pre-Mongol Arabic sources. ${ }^{25}$ Due to a lack of evidence, it is unclear, therefore, if the anecdotal tales contained in Rose Garden, although allegedly based on Sa'di's travels, were in fact gleaned from oral tradition and poetically embellished, or are, in fact, wholly literary creations.

Nevertheless we can see the importance of Sa'di's Gulistān by its numerous translations into European languages in the 17th century. Notably, a partial French translation by André du Ryer which was published in Paris in 1634 under the title Gulistan's Empire of Roses (Gulistan ou l'Empire des Roses), followed by a German translation by Friedrich 
Ochsenbach in 1636, and a subsequent Latin translation, accompanied by the Persian text, by Georgius Gentius in 1651. In spite of such work, it is odd that the text was not translated into English until the late 18th century, with partial translations of sections by Stephen Sulivan (1774), followed by more substantial renderings in prose by Francis Gladwin (1806) and James Ross as The Gulistan, or Flower-Garden of Shaikh Sadî of Shiraz (1823). Although these translations facilitated the spread of this particular 'tied stones and loose dogs' tale into numerous European languages as early as 1634, it is significant that there is a version in English, in John Taylor's Wit and Mirth (1626), which predates all the modern European translations of Gulistān. Such evidence would suggest one of two possibilities: either that polygenesis is at play and this tale developed independently or, which seems more likely, that the tale was told again by someone in England for different purposes.

\section{WIT AND MIRTH (1626) AND THE ENGLISH \\ JEST-BOOK TRADITION}

Taylor's work was part of the English Jest-Book tradition, which had originated in the 15th and 16th centuries with the publication of A Hundred Mery Tales (1526 [Hazlitt 1887]) and Mery Tales, Wittie Questions, and Quicke Answeres (1567). Jest-tales are short, comic prose-tales and humorous anecdotes that are typically mono-episodic and highly framed with elements of local colour, such as proper names, localities, and professions. Collected originally in English jest-books of the 15th and 16th centuries, the genre of jest-tales blurred the boundaries between oral and literate cultures on account of the similar performances required for public storytelling to a largely illiterate audience and for public joking to ensure cultural embedding (Reinke-Williams 2009: 327). These collections drew heavily, both in terms of inspiration and indeed subject matter, on the inspiration of Humanist literature of the early renaissance (see Woodbridge 2003), particularly the seminal works of Poggio Bracciolini's Facetiae (1470) and Baldassare Castiglione's Il Libro del Cortegiano (1528). Other important sources were 12th and 13th century fabliaux composed by French jongleurs, which were reworked in the Decameron of Boccacio and first appeared in English in $1620 .{ }^{26}$ In spite of these influences, it is widely acknowledged that Hundred Mery Tales (1526) and Mery Tales, Wittie Questions, and Quicke Answeres (1567) were the foundation for almost all other subsequent works in the genre in England.

Unlike most jest-books, Taylor's Wit and Mirth was exceptional in that it borrowed few stories from preceding collections. Instead, his modus operandi primarily involved fieldwork, collecting material predominantly from the oral tradition "out of Tauernes, Ordinaries, Innes, Bowling Greenes, and Allyes, Alehouses, Tobacco shops, Highwaies, and Water-passages" (Taylor 1626: title page). Autobiographical evidence also shows that his fieldwork was not limited to London, nor indeed England, but that Taylor had travelled throughout Continental Europe during this period before 1626, including Spain, the Azores, the Netherlands, Belgium, Prussia, and Bohemia (Waage 1973; Capp 1994; 2004; Chandler 1999). It is highly likely, therefore, that the following jest-tale was one of the travelling oral narratives that circulated widely during this period: 
A country fellow (that had not walked much in streets that were paved) came to London, where a dog came suddenly out of a house, and furiously ran at him, the fellow stooped to take up a stone to cast at the Dogge, and finding them all fast rammed or paved in the ground; quoth he, what strange Country is this, where the people tye up the stones, and let the dogs loose (sic).

Whilst there are structural similarities with Sa'di's tale, this narrative fits the requirements of local culture and tradition, particularly those aspects of content and style that von Sydow (1934) has noted as being common in ecotypes. The core conflict in Sa'di's tale between the explicit exotic protagonist (the poet) and antagonists (the amir and the robber gang), which is motivated by a recognisable, hierarchical power/status relationship, is not evident here. Instead Taylor's tale establishes both character type and conflict through the tacit invocation of subliminal socio-geographic and socio-economic stereotypes that are peculiar to the immediate environment. The protagonist, a country fellow, is asymmetrically juxtaposed against his location - London - which invites a reading of conflict based on the stereotypical centre-periphery oppositions of the urban-rural model: the dominant geographic centre (the city = London) is perceived as being advanced, modern, dynamic and progressive; whilst the periphery (the countryside) is primitive, old-fashioned, static, and regressive. ${ }^{27}$ The protagonist is revealed, therefore, not by explicit characterisation, but by orientating the audience to its own reading of the character via culturally conventionalised stereotypes of the rustic country fellow, i.e. naïve, unsophisticated and dull-witted, as evidenced by his ignorance of a fundamental aspect of metropolitan life: that the streets are paved with stones. The character of the country fellow is, of course, an institutionalised stereotype that is representative of an entire social class - the non-metropolitan masses - and has been perpetuated in folklore and popular literature since the 16th century, although the basic dichotomy stretches as far back as classical antiquity (see Williams 1973: 1). Indeed, the stereotypical characteristics associated with the country fellow, as a social type, fit neatly with those of the fool as outlined by Orrin E. Klapp (1949: 158) "[...] a demonstration of deficiency of intelligence or wit places a person in the category of the simple fool. He is classed as naïve, senseless, backward, or rustic." In this instance, of course, these qualities are embedded in the stereotype, so there is no need for any explicit description of character.

From a functional perspective, the use of the place-name London to situate the tale in a specific locale is an important device for regionalising the lore in its new ecological environment. It is also a means of asserting its veracity to the audience and authenticating the tale to ensure its adaption, acceptance and survival. If we accept that the tale-text may, to a less or greater extent, reflect aspects of the social relations, ideas and values in the society in which it is performed (see Barber 2007: 2) (or, in the case of written narratives, read), place-names may be viewed as a key mechanism for operationalising a matrix of esoteric secondary interpretations associated with socio-economic, cultural and political behaviours. It is interesting, therefore, that the use of London in this case, whilst clearly reflecting the primary urban-rural oppositions, also has secondary undertones associated with contemporary religious, political and social upheaval in pre-Civil War England, ${ }^{28}$ especially the growing schism and enmity not only between religious groups, but also between "common people and the gentry, and between the 
country and city dwellers" [emphasis mine] (Fritze and Robison 1996: 88). ${ }^{29}$ It is important to state here that Taylor is undoubtedly motivated by the performative realities of telling tales to, and writing tales for, an urban audience. The in-group audience of citydwellers (both aural and literary) has performative expectations related to the butt of the mockery, i.e. it expects to mock the out-group located on the periphery (the country folk). These expectations must be met if the text is to fulfil its function. Indeed, it is well attested that Taylor, as "Renaissance Everyman" (Boerth 2000: 915) often used such stereotypical tropes to elicit responses from his audience and to "...reinforce(s) the cultural values of his urban audience in flights of comedy" (Waage 1973: 596). This rural class is viewed to have an inferior status to that of urban city dwellers (in this case London) and to possess a substandard socio-economic status and value system, as well as concomitantly low intellectual, moral and behavioural standards. It is also noteworthy in light of these performative considerations that while the kernel element of tied stones and loose dogs remains, the tale ends abruptly on this punchline instead of the resolution of conflict and attendant moral maxim in Sa'di's tale, which, as we have seen, mirrors Labov and Waletzky's (1967) clausal structure of narrative. Francis Lee Utley (1975) has argued that such punchline tales are indicative of a distinct city-joke in which literate storytellers familiar with print culture reconstructed short tales from the punchline.

\section{PERIODICALS, PAMPHLETS AND NEWSPAPERS (18TH AND 19TH CENTURY)}

Since its publication in 1626, the jest-tale featuring the kernel tied stones and loose dogs has appeared at least 44 times in English language periodicals, newspapers, and jestbooks (see Appendix 1). The textual chain shows, however, that after Taylor's publication it does not appear in print again in England for almost 125 years, but this is punctuated by a flurry of activity in the formative years of the newly-established United States beginning in 1798 and continuing throughout the 19th century. The first occurrence is in The Weekly Magazine of Original Essays, Fugitive Pieces, and Interesting Intelligence (Anon.) printed in 1798 in Philadelphia, where the tale appears as follows:

An Irishman just arrived from Cork, was walking along one of the streets of London. Being attacked by a large dog, he stooped down to pick up one of the stones, but it was fast. "Arrah!" says he, "what a pretty country is this, where the stones are tied and the dogs let loose."

The tale structurally mirrors Taylor's earlier version, although there is a discernible change in the detail of the protagonist: the generic country fellow has been replaced by a specific characterisation of an immigrant Irishman, from Cork, who has just arrived in London and is struggling with life in the metropolis, and naively gesturing "what a pretty country this is, where the stones are tied and the dogs let loose". As we can see, the power-dynamic is no longer based on an institutionalised urban-rural dichotomy, but instead seizes upon a specific national stereotype as the exaggerated exemplar of the rural: the cultural stereotype of the stage Irishman. The specified locale of Cork, which is one of the most of southwesterly counties in Ireland and, by extension, farthest 
from the urban centre of Dublin, is a means of embedding the rusticity of the character in terms of geography, culture and behaviour. Of course, these stereotypes were not based on experiential data, however, and it would be wrong to assume that they were generated by societal adjustment to intergroup transactions with immigrant communities. As Dale Knobel (1981: 50) and others have pointed out, during this emergent period American writers struggled with the literary possibilities of identifying native characters and so they engaged in a process of appropriation from the English tradition, which invariably led to the importation of stereotypes:

[...] the American stage Irishman was imported full-blown from England at the end of the eighteenth and the beginning of the nineteenth centuries. The English stage Irishman had a long history traceable at least to the era of Shakespeare... Therefore, the argument runs, the stage Irishman that mid nineteenth-century Americans became familiar with was really a traditional English representation of the Irish full of specifically English prejudices about and ignorance of the real Irish.

Such stereotypes proved to be cultural antecedents to the actual experience of Irish communities as soon was to be the case. By the early 19th century and as the first mass wave of immigration to the United States, the Irish were quickly identified as the Other and definite stock stereotypes based on English biases became apparent as early as the 1830s (Knobel 1981: 49). Whilst the Irish stereotypes focused on typical traits such as appearance (small, hirsute and simian), behaviour (belligerent, alcoholic, and supplicating), character (dull-witted, rustic, and guileless), and language (God-fearing, confused, and malapropian), the majority of characterisations appeared as Irish bulls (also known as Hibernicisms). These bulls, as seen previously, were expressions containing a manifest contradiction in terms or involving a ludicrous inconsistency unperceived by the speaker. Originally, these were items of wordplay unconnected to any particular people, but soon become associated with the supposed intellectual deficits and naiveté associated with the Irish peasants' adjustment to urban life in the US and featured prominently in popular satirical magazines such as Puck, Judge and Life. ${ }^{30}$

During the 19th century the jest-tale experienced two periods of sporadic activity in the USA and Canada: in 1851 ${ }^{31}$ and between the years 1870-1872.32 Throughout these peaks in usage, it is attested almost verbatim in numerous local and state newspapers on the east coast, as well as in The Book of Blunders: Comprising Hibernicisms, Bulls that are not Irish and Typographic Errors (1871), a popular collection of Irish anecdotes collected by Charles Carroll Bombaugh. This structural fixity coupled with two distinct peaks in usage would suggest a high degree of borrowing between publications in this period as Paul Zall (1980: 3) contends was a typical feature of such publications: "They copied not only from one another but, in a happy symbiotic cycle, copied from and were copied by almanacs, newspapers, and periodicals."

From the corpus, I have discerned two main variant forms, which I have termed Tale A and Tale B. The first of which, Tale A (below) is first attested in 1830 in a collection published in Boston entitled The Galaxy of Wit: Or, Laughing Philosopher, Being a Collection of Choice Anecdotes, Many of which Originated in Or about "The Literary Emporium" (Johnston 1830). The version is as follows: 
Tale A: USA 1830-1868 ${ }^{33}$

An Irishman who had left his native country, and sought an asylm [sic] in America because it was a land of liberty, was attacked on his first arrival in December by a furious mastiff. He stooped to pick up a stone to defend himself, but the stone was frozen fast. "By my sowl," says Pat, "now is not this a swate land of liberty, where the dogs are let loose, and the stones tied fast!" ${ }^{34}$ [Emphasis mine.]

This version of the tale demonstrates clear ecotypical adaptations associated with the American émigré experience. The main change relates to the explanation that the Irishman is an immigrant who has arrived in the USA in search of asylum and is vexed at how he can be attacked so unjustly in a land of liberty. Whilst the core conflict is related to the Othering associated with the native vs. foreign dichotomy, the perceived inequality or disadvantage is also foregrounded with reference to the "land of liberty". The specific locale of Cork, as seen in the first American example of 1798, is omitted and instead there is an explicit identification of nationality, i.e. Irishman, accompanied, one assumes, by a series of implicit attendant stereotypes. The character's name is the stereotypical "Pat", which is an abbreviated version of Patrick, ${ }^{35}$ and the language is clearly marked with hackneyed renderings of what is purportedly Irish regional speech as found in the adjective swate 'sweet' and the exclamation "By my sowl" (an HibernoEnglish form of the Irish language expression "Ar m'anam" 'on my soul'). ${ }^{36}$ Dialectal markers such as these are typical of a general tendency in the English 16th century jest-books to use colloquialisms and clichéd regional forms, particularly dialectal lexis and morphology, to characterise rustic (English) northerners, and in later times, people from the south-west of England, as well as the Irish, Welsh and Scottish. ${ }^{37}$ Moreover, according to Brian Earls (1988: 17) the accent was a key indicator of genre: "The brogue in particular, which Edgeworth considered a great and shameful defect, would appear to have acted as a signal which predisposed hearers to anticipate (Irish) bulls" [emphasis mine].

Tale B is more generalised and void of the previous orientation about the emigrant status, yet the Irishman remains as protagonist. Once again, the particular locale is not mentioned, he is merely "travelling in a street". Similar to Tale A, however, the Irish stereotype is embedded with the use of dialectal features: the term Arrah (an Anglicised rendering of the Irish-language interjection $A r u^{\prime}{ }^{38}$ which is used to express surprise or excitement) is viewed to be a characteristic feature of Hiberno-English speech. The state of disadvantage and imbalance is also more general, merely indicating the character's incredulity with the simple exclamation "what a fine country [var. what a country] is this".

Tale B: England, Wales, USA: $1854-1883^{39}$

An Irishman, travelling in a street that was paved, was met [var. startled, accosted] by a dog with a threatening growl. The traveller attempted to pull up one of the paving-stones to throw at him, but it was fast, "Arrah," said Paddy, "what a fine country [var. what a country] is this, where stones are tied, and dogs let loose!

In both Tales A and B, the use of "Pat/Paddy", the dialectal features and the incongruence of the jest fit well with the characteristics of the stage Irishman identified by Maurice Bourgeois in his seminal work John Millington Synge and the Irish theatre (1913: 109-110): 
The stage Irishman habitually bears the general name of Pat, Paddy, or Teague. He has an atrocious Irish brogue, perpetual jokes, blunders, and bulls in speaking, and never fails to utter, by way of Hibernian seasoning, some wild screech or oath [for example bedad, begorra, alanna, sthore, arrah, by chrish la, etc.] ${ }^{40}$ of Gaelic origin at every third word.

While, in the main, the tale features as a jest-type anecdote mocking the naiveté of the Other, and typically located in the Wit and Mirth section of newspapers, sources show that by the mid-19th century the tale was also being used in serious political discourse. The contentious socio-political climate of the period sees the expression often used in political rhetoric for the purposes of cautioning against the type of state of unfairness epitomised in the jest. ${ }^{41}$ This alternative reading of the tale script foregrounds a more empathetic consideration of the inherent unfairness of the character's circumstances, i.e. being attacked without recourse to means of defence. The change in usage that has been effected by this new reading is accompanied by structural adaptation also. The tale is redacted to the kernel element of tied stones and loose dogs, which, as a catchword, appears sufficient for readers to recall and represent the meaning of the tale. This is significant for not only does it identify a period of transformation in usage and meaning, but it also indicates that the tale was both recognisable and current within the contemporary cultural idiom. For example in 1847 in a letter from B. C. Gilbert (1847), published in the Anti-Slavery Bugle, the phrase was used as part of a plea to argue the case for emancipation free from attack:

Anti-Slavery Bugle (New-Lisbon, OH), July 23, 1847.

I am not obnoxious to the charge of being particularly friendly to the Garrisonian scheme of emancipation, and all I ask for him or friends is that they may have a fair chance to vindicate themselves from what they deem false or slanderous charges. Such treatment as they received at the hand of brother White, is of the same stripe of Paddy's, when villagers tied the stones all fast and let dogs loose upon him. [Emphasis mine.]

\section{IRISH FOLKLORE SOURCES}

During the mid-19th century, at the same time as the jest-tale was circulating in America, Canada and England, versions of the tale are also found in a number of Irish-language publications. The first recorded example in Lia Fáil in 1851 features a story called "Eachtra na gConnachtach" ('The Adventure of the Connaught people'). Reverting to the urban-rural dichotomy, the humorous tale parodies the plight of agricultural migrant workers from the province of Connaught coming to the city of Dublin in search of employment. Every conceivable anecdote and witticism has been compiled in the story to show "how unaware, ignorant, how senseless, and how craven" the Connaught people are (De hÍde 2013: 153, translation mine). Amongst these tropes we find a version of the tale, which, interestingly, no longer features the punchline but instead relies on situational content for the purposes of humour. 
Then we came through Murder Town where the stones were tied and the dogs loose. A large dog came out and bared his teeth at the fearless fellow, and then the fearless fellow bared his teeth back. The fearless fellow thought that if he struck the dog that its owner would come out and that he himself would be beaten. Without yielding to that, the fearless fellow drew his fist and floored the dog. Then out came the owner and grabbing the fearless fellow shook him from side to side, and then floored him with a kick of his leg. I thought, my friend, that he had made a windmill of his body, but in the end he let him go. (De hÍde 2013: 169; translation and emphasis mine.)

Towards the end of the century more familiar versions can be found in printed sources of Irish-language folk tales that were collected in Ireland, namely in (i) The Irish Language Miscellany (1876) in a story called "Eachtra Sheamuis Gray le Donchadh Mhic Namara" ('The Adventure of Seamus Gray by Donnchadh Mac Namara'), and also in (ii) a story published in Irisleabhar na Gaedhilge ('The Gaelic Journal') in 1897. Here below are translated versions of those two stories.

(i) Sometime after that Eilis Orum went to Whitestown on a frosty morning; a dog from the big house ran to bite her but she couldn't get a stone, because they were all frozen by the frost, and it was then that she said: Whitestown is an awful place; there are tied stones and loose dogs (O’Daly 1876: 68; translation mine).

(ii) Eibhlín was in Whitestown on a frosty day, she was being chased by dogs and the stones were so fixed to the ground by the frost that she couldn't throw them, so she said this verse: it ill befits you, oh people of Whitestown, to have stones tied and dogs loose when Eibhlín falls as often as she gets up. (Anon. 1897: 151; translation mine).

It is well understood that ecological changes occur during the transmission of folklore from one region to another to ensure the adaptation and survival of the item. The assigning of Whitestown as the specific locale is a means of regionalizing - embedding and preserving - the tale as a valid, authentic item of local folklore which the local 'folk' group can utilise. Of course, tales are also expected to produce certain effects and to elicit certain responses from the audience. In this particular tale, the issue of agency appears to be important in this regard. There is an identifiable difference in the function of the tale when used in this cultural milieu by a rural, local folk community: it is no longer the empowered in-group that mocks a less powerful out-group on account of the naiveté and gullibility of the protagonist outsider (be that the rural or immigrant outsider), but instead the tale explicitly directs the vilification at the place in which the event occurred. The explicit denigration of Whitestown clearly carries the implication that the local people are not to be trusted also; they are unjust, corrupt and crooked. Of course, the motivation for ascribing these particular qualities to Whitestown and its population is unclear without contextual information, but it appears that it is an example of the mutual raillery and verbal jousting amongst neighbouring villages and parishes - often for the purpose of strengthening own group identity - which were characteristic of 19 th-century blason populaires. ${ }^{42}$

By the early 20th century there is evidence in two Irish dialectal proverb collections, Seanfhocail na Muimhneach ('The Proverbs of the Munster people', Ó Siochfhradha 1926) 
and Seanfhocla Chonnacht ('The Proverbs of Connaught', uí Bhraonáin 2010; cf. Ó Máille 1948 ; 1952) that the jest-tale relating to Whitestown had been condensed into a brief multi-word fixed expression. It is important to note that, in the main, these proverb collections were collected from the oral tradition and thus are a valuable barometer of the active proverbial repertoire of Irish speakers in the late 19th and 20th centuries. Yet, it should also be emphasised that much of the material in these sources is not what contemporary paremiologists would consider proverbs. Along with 'true' proverbs, the collections contain an assortment of other traditional fixed expressions, including proverbial phrases, proverbial comparisons, triads, curses, blessing and weather beliefs. This is further complicated by the lack of classification, which means that for the nonspecialist it may be difficult to distinguish between multiple sub-genres.

In Seanfhocail na Muimhneach we find the kernel expression as an explanatory element in a blason populaire mocking the village of Ballyneety: "Pity the person who goes to Ballyneety: there are tied stones and loose dogs" (Ó Siochfhradha 1926: 115; translation mine). The idea of inhospitableness is codified by the explicit negativity of the first sentence statement, but also by the situational tension arising from the incongruity of the subsequent explanatory sentence. In case readers were not aware of the meaning, the editor also provides the following gloss, "It is common to say this about many towns in Ireland. Some person who wasn't shown proper hospitality there on a freezing, frosty day. When the dogs of the town chased him, he wasn't even able to find stones" (ibid.; translation mine). Unfortunately, this particular collection provides no ancillary information relating to its provenance, but fortuitously Prof. Dáithí Ó hÓgain (2004) has identified the source as Ballyneety (also known as Whitestown), Co. Limerick. ${ }^{43}$ Considering that this provincial proverb collection has been collected primarily from oral speech, it would suggest that the expression was current in the oral tradition in this area. Interestingly, a similar Hiberno-English version of the tale mocking the town of Cookstown, Co. Tyrone, in the north of Ireland was also recorded in this period by John Marshall (1931: 68), who claims the tale was in circulation in the oral tradition in the mid-19th century, although he provides no evidence to support this claim:

It was then looked upon as an ancient story, and was told of a half-witted mendicant named Raymond, who passed through the town during a severe frost. Tormented by the small boys and attacked by dogs, his passage through the long town took him three weeks. When at length he got clear of it he looked back, shook his stick at it and cursed it 'Bad luck to you, long Cookstown, where the stones are chained and the dogs loose!'

Returning to the Irish proverb texts, there is also evidence from a neighbouring dialect contained in Seanfhocla Chonnacht, where the following entry appears: §2711 “On a frosty day, the stones are frozen and the dogs loose" (uí Bhraonáin 2010: 179; translation mine). The explanatory notes declare that the expression is found in Hiberno-English as a synonym for 'imbalance' and that the expression was originally taken from a tale relating to a local beggar. ${ }^{44}$

One final source of folklore and local tradition that should be included in evidence is the Schools' Collection (1937-1939), a scheme initiated by the Irish Folklore Commission, which contains approximately 740,000 pages of folklore from the period (see NFC 2018). A search of the transcribed database shows that tale was current in the English 
language circa 1937-1939 and that, reminiscent of the jest-tale of the 17th-19th centuries, the mockery follows the urban-rural model, in this case honing in on the agricultural farmer as the butt of the joke.

A farmer's son who had always lived in the country, was paying a visit to his uncle in the city. As he was walking along the streets a bulldog attacked him. The boy naturally tried to find a stone to throw at the dog. But the road was made with paving stones lightely [sic] rammed down and fixed. When he could find no stones he said "this is an odd place where all the stones are tied up and all the dogs let loose." (NFCS 1034:160)

The database also has evidence of its use in the Irish language, where it is recorded from a 73-year-old informant, Píaras de Bhál, from Knocknaree, Co. Waterford:

A woman begger called Máire used to go about the place and one hard, frosty morning she came to a farmer's house and the dogs attacked her and knocked her down as soon as she would get up. In the end she managed to escape from them and she said: Barra na hUidhre is a sorry town, the stones are tied and the dogs loose, and poor Máire knocked down as quick as she can get up. (NFCS 0656:005; translation mine.)

There is a notable change in the use of the expression in Irish-language literary sources of the 20th century, where the punchline has been clearly extracted as a catchword for the entire jest. In these sources, the expression operates as a synonym for danger that cannot be defended or prevented, quite similar to its mid-19th century usage in US political periodicals and newspapers. There is no need to delve too deep into these sources due to the replication of the form, but the following translated examples give a flavour of this (translations mine):

We tied to a ceasefire and you breaking it! 'Tied stones and loose dogs!' That will not do, Sir! (O'Leary 1931: 174)

The stones were tied and the dogs loose. One group was free to do good or bad, and they were bullying the others who were not able to defend themselves. (Mac Síthigh 1940: 76)

Tied stones and loose dogs: letting cowards have their way while decent people have no control of them. (Ó Riain 1952: 52)

"Stones stuck and dogs aloose": Danger that cannot be prevented. (Ó hAodha 1970: 50)

\section{USAGE IN THE IRISH LEGAL SYSTEM}

In 1971 the phrase 'tied stones and loose dogs' gained currency in legal terminology as an exemplar of imbalance, disadvantage and injustice. In a celebrated case Re Haughey [1971] IR 217 the then Chief Justice, Cearbhall J. Ó Dálaigh, made a seminal judgment establishing the rights of the witness to defend him/herself in cross-examination, i.e. le principe d'égalité des armes, ${ }^{45}$ a right which might be regarded as the opposite of that 
state of disadvantage embodied in the expression tied stones and loose dogs. He had the following to say:

Where, as here, it is considered necessary to grant immunity to witnesses appearing before a tribunal, then a person whose conduct is impugned as part of the subject matter of the inquiry must be afforded reasonable means of defending himself... To deny such rights is, in an ancestral adage, a classic case of clocha ceangailte agus madrai scaoilte [tied stones and loose dogs] Article 40, s. 3, of the Constitution is a guarantee to the citizen of basic fairness of procedures.

Although the substance of this right is enshrined within the concept of natural justice or audi alteram partem ${ }^{46}$ and is explicitly protected by Article 6 of the European Convention on Human Rights (1950, Council of Europe), Ó Dálaigh was appropriating and nativising the right through the lens of Irish experience by invoking the claim that the tale was an "ancestral adage". Following this precedent the phrase was referred to in a number of other cases and has almost become proverbial in legal circles as a byword for imbalance and injustice. ${ }^{47}$ For example, in a speech to Delegates of the Law Commissions, Michael D. Higgins (2012), President of the Republic of Ireland, described how the important principle of natural justice was the antithesis of the state of disadvantage described as "tied stones and loose dogs". He noted that this phrase was recognised in law and that it was "an ancestral Irish adage which has a folk tale behind it". Of importance here, of course, is not the veracity of the claim itself, but the creation of intertextual relations with 'the folk' via the invocation of ancestral voices. These linkages are a means of lending meta-discursive authenticity to the 'text' to establish the authority of the performer, in this case the President of Ireland, and in so doing, validating a social and political agenda (see Briggs 1993: 391). The legal precedent of 1971 was also responsible for the dissemination of the expression in the lower house (Dáil Éireann) of the Irish legislature (Oireachtas) where there is evidence of its use in parliamentary debates at various times throughout the same period. In these debates, it is typically invoked as an explicit "old Irish proverb" with an associated introductory formula such as "...as the [Irish] proverb states", although as we have seen earlier the expression is not technically a proverb. ${ }^{48}$ Aside from legal usage it appears that the expression is no longer in currency in Ireland and, more significantly, apart from two contemporary sources, one in Russia and the other in Pakistan, there does not appear to be any evidence for its use internationally. ${ }^{49}$

\section{CONCLUSIONS}

Inspired by the work of Hasan-Rokem $(2000 ; 2003)$ and Hopkin $(2003 ; 2016)$ in re-evaluating von Sydow's (1932) concept of the ecotype, this study has shown that folk idioms or expressions are a fertile area of research that can be deconstructed using exhaustive literary and historical research based on the historic-geographic method. At the heart of this template, I would contend, is the need to read texts within their contemporary cultural, historical and socio-economic frameworks to decode meanings according to instantiation, the motivations for their use, and the question of agency in folk groups. By collecting, examining and construing inter-relations between folkloristic texts across a 
range of cultural products - folklore collections, popular culture periodicals and political discourse - and by informed cultural contextualisation of its instantiations, we can re-construct the extensive cultural underpinnings that inform a range of everyday folk expressions.

As a case study of ecotype development, this study has shown that the Irish language expression clocha ceangailte agus madraí scaoilte ('tied stones and loose dogs') is primarily recognised in the modern era as a synonym for a state of disadvantage, unfairness and imbalance. This semantic delineation can be attributed to its use in a legal precedent in 1971, namely Re Haughey [1971] IR 217, in which the expression was institutionally codified and subsequently propagated in the common register of the legislative and judicial branches of the Irish government. The phrase appears to be a recent introduction to the Irish language via the ecotypification of an international jest, in which the punchline was extracted as a catchword for the entire jest-tale.

The exact source of the expression is enigmatic, but a moral tale on the advantages of silence, first recorded in Sa'di's Gulistān (1258), shares many structural parallels. Whilst the original Persian tale was translated to numerous European languages, such as English, French, German, and Latin, in the 17th century, a similar version recorded in 1632 in Taylor's Wit and Mirth predates these translations and shows that the tale may well have been a migratory oral tale, representative of locally-adapted variants, or ecotypes (Sydow 1932). This process of ecotypification in England in the 17th-19th centuries was motivated by socio-economic, cultural and political imperatives. In this instance, we can see that 17th-century Londoners, as a folk in-group, use the jest-tale to mock those on the periphery, i.e. the non-metropolitan class of whom they had established stereotypes relating to stupidity and backwardness. The jest-tale is essentially a condensed objectivation of Said's (1978) Othering based on an urban-rural dichotomy that, having been moulded in narrative form, is highly reflective of contemporary societal tensions in London.

The mass borrowing of English jest-tales by the American market in the formative years of the United States was also accompanied by the replication and perpetuation of stereotypical forms related to English cultural tropes and biases. Primarily focussing on the negative stereotypes about the Irish, the jest-tale was gradually adapted to the American ecology along clear lines of development which saw implicitly accepted stereotypes replaced by more explicit identifiable socio-cultural markers such as language and accent, stereotypical names (i.e. Pat or Paddy), linguistic contradictions, and quasireligious interjections and exclamations. The ecotype was grounded in the social and cultural climate of the time, reflecting the socio-economic, political and cultural mores. Adaptations were generated by the audience's cultural tropes, especially regional and cultural values simplified as stereotypes, in response to the socio-economic changes brought about by 19 th-century Irish immigration. The fact that this stereotyped tale circulated widely within the United States without any significant change in detail shows that this was a national ecotype, originally imported and adapted to a new ecology and, as such, was an example of the power of "culture's reshaping propensities" (Dundes 1962: 173).

Ecotype development, of course, does not follow chronologically especially when we consider the limited distribution of popular print sources such as chapbooks, pamphlets and newspapers, the fact that they are often locally-based, and the lack of cross- 
linguistic contact in the 17th-20th centuries. The appearance of the jest-tale in Irish-language sources of the 19th century may constitute evidence of borrowing from English sources prior to its adaptation in America in the 18th-20th centuries. As before, the humour in these versions is sometimes derived from the urban-rural dichotomy (as in the Dublin-Connaught split), but there is also ample evidence of a significant functional adaptation in other versions (the case of Whitestown or Cookstown): mocking is now directed not at the protagonist but at the location. This is supported by evidence of the kernel expression in proverb collections. It appears to be an example of the verbal jousting between neighbouring villages and towns that are characteristic of blason populaires, and which are used by folk in-groups to simultaneously deride its neighbours and strengthen its own group identity.

As a final comment, I should acknowledge that this study raises familiar questions about the oral-literary debate and the almost immutability of the text, which I have not sought to examine here. Scholarly work on these questions in the Irish tradition have been discussed in detail by the likes of Almqvist (1975) 50 and Seán Ó Coileáin (1977), yet the international scholarly consensus for the past 20 years or more has generally supported the idea of the constant fluid interplay between the oral and written traditions, between the verbal and the non-verbal. ${ }^{51}$ It is clear from this study that attempting to accurately trace such historic interconnections is often extremely difficult due to the absence of documentary evidence, particularly from the ethnographic perspective, and that any possible conclusions would be speculative at best. Nevertheless, if we accept that (as Beyer 2011 has argued so convincingly) institutional folklore archives only contain a tiny fragment of what constituted folklore in previous centuries, then there is a clear need for an analysis of cultural material outside of institutional folklore repositories - literary sources, newspapers, popular culture periodicals, pamphlets and political discourse - and weighted against contemporary socio-economic and historical evidence so that we may shed a brighter light on processes of transmission, dissemination and ecotypification across time and space.

\section{APPENDICES}

Table 1. International Distribution of 'tied stones loose dogs' jest-tale

\begin{tabular}{|l|l|l|l|}
\hline Title & Location & Source-type & Date \\
\hline Wit and Mirth & London & Book & 1626 \\
\hline $\begin{array}{l}\text { The Weekly Magazine of original essays, fugitive } \\
\text { pieces, and interesting intelligence }\end{array}$ & Philadelphia & Book & 1798 \\
\hline $\begin{array}{l}\text { The Examiner: Containing Political Essays on the } \\
\text { Most Important Events of the Time; Public Laws and } \\
\text { Official Documents }\end{array}$ & New York & Book & 1814 \\
\hline $\begin{array}{l}\text { The Galaxy of Wit: Or, Laughing Philosopher, Being } \\
\text { a Collection of Choice Anecdotes, Many of which } \\
\text { Originated in Or about "The Literary Emporium" }\end{array}$ & Boston & Book & 1830 \\
\hline $\begin{array}{l}\text { The Aurora Borealis: Or Flashes of Wit; Calculated to } \\
\text { Drown Dull Care and Eradicate the Blue Devils }\end{array}$ & Philadelphia & Book & 1831 \\
\hline Neww-York Spectator & New York & Newspaper & $17 / 07 / 1841$ \\
\hline
\end{tabular}




\begin{tabular}{|c|c|c|c|}
\hline Jeffersonian Republican & Stroudsburg, PA & Newspaper & $21 / 05 / 1846$ \\
\hline The Columbia Democrat & Bloomsburg, PA & Newspaper & $30 / 05 / 1846$ \\
\hline Anti-Slavery Bugle & New-Lisbon, $\mathrm{OH}$ & Newspaper & $23 / 07 / 1847$ \\
\hline Sangamo Journal (Illinois State Journal) & Springfield, IL & Newspaper & $11 / 01 / 1851$ \\
\hline $\begin{array}{l}\text { The Huddersfield Chronicle and West Yorkshire } \\
\text { Advertiser }\end{array}$ & $\begin{array}{l}\text { West Yorkshire, } \\
\text { England }\end{array}$ & Newspaper & $12 / 04 / 1851$ \\
\hline The Northern Star and National Trades' Journal & Leeds, England & Newspaper & $12 / 04 / 1851$ \\
\hline The Preston Guardian & Preston & Newspaper & $19 / 04 / 1851$ \\
\hline $\begin{array}{l}\text { The Leicester Chronicle: Or, Commercial and } \\
\text { Agricultural Advertiser }\end{array}$ & Leicester & Newspaper & $26 / 04 / 1851$ \\
\hline Semiweekly Camden Journal & Camden, SC & Newspaper & $29 / 08 / 1851$ \\
\hline Diprose's Funny Book & London & Book & 1854 \\
\hline The Weekly Comet & Baton Rouge, LA & Newspaper & $15 / 01 / 1854$ \\
\hline $\begin{array}{l}\text { Cheshire Observer and General Advertiser: For } \\
\text { Cheshire and North Wales }\end{array}$ & Chester & Newspaper & $01 / 12 / 1854$ \\
\hline The Bradford Observer & Bradford & Newspaper & $21 / 08 / 1862$ \\
\hline Nashville Union and Dispatch & Nashville, TN & Newspaper & $12 / 07 / 1867$ \\
\hline Staunton Spectator & Staunton, VA & Newspaper & $23 / 07 / 1867$ \\
\hline Wyoming Democrat & $\begin{array}{l}\text { Tunkhannock, } \\
\text { Wyoming County, } \\
\text { PA }\end{array}$ & Newspaper & $28 / 08 / 1867$ \\
\hline The Daily Phoenix & Columbia, SC & Newspaper & $12 / 04 / 1868$ \\
\hline Arizona Miner & Fort Whipple, AZ & Newspaper & $14 / 04 / 1868$ \\
\hline Daily Ohio Statesman & Columbus, $\mathrm{OH}$ & Newspaper & 05/05/1868 \\
\hline The Hampshire Advertiser & Southampton & Newspaper & $04 / 09 / 1869$ \\
\hline The Bristol Mercury & Bristol & Newspaper & $18 / 09 / 1869$ \\
\hline Memphis Daily Appeal & Memphis, TN & Newspaper & $16 / 12 / 1869$ \\
\hline The Ottawa Free Trader & Ottawa, IL & Newspaper & $15 / 01 / 1870$ \\
\hline $\begin{array}{l}\text { Cheshire Observer and Chester, Birkenhead, Crewe } \\
\text { and North Wales Times }\end{array}$ & Chester & Newspaper & $29 / 01 / 1870$ \\
\hline The Newcastle Courant & $\begin{array}{l}\text { Newcastle-Upon- } \\
\text { Tyne }\end{array}$ & Newspaper & $04 / 02 / 1870$ \\
\hline The Bloomfield Times & Bloomfield, NJ & Newspaper & $15 / 02 / 1870$ \\
\hline $\begin{array}{l}\text { The Book of Blunders: Comprising Hibernicisms, Bulls } \\
\text { that are not Irish and Typographic Errors }\end{array}$ & Philadelphia & Book & 1871 \\
\hline Waynesboro Village Record & Waynesboro, PA & Newspaper & $18 / 04 / 1872$ \\
\hline Aberystwyth Observer & Aberystwyth, Wales & Newspaper & 02/01/1875 \\
\hline The Wheeling Daily Intelligencer & Wheeling, WV & Newspaper & $17 / 02 / 1876$ \\
\hline Pictures of Our Representative Men & Sacramento, CA & Book & 1880 \\
\hline Cambrian & Aberystwyth, Wales & Newspaper & $17 / 08 / 1883$ \\
\hline Perrysburg Journal & $\begin{array}{l}\text { Perrysburg, Wood } \\
\text { County, OH }\end{array}$ & Newspaper & $03 / 12 / 1886$ \\
\hline Liverpool Herald & Liverpool, NSW & Newspaper & 08/11/1902 \\
\hline
\end{tabular}




\begin{tabular}{|l|l|l|l|}
\hline The Advocate & Sturgeon Bay, WI & Newspaper & $05 / 10 / 1903$ \\
\hline Kapunda Herald & $\begin{array}{l}\text { Kapunda, South } \\
\text { Australia }\end{array}$ & Newspaper & $02 / 06 / 1905$ \\
\hline Los Angeles Herald Sunday Magazine & Los Angeles, CA & Newspaper & $14 / 02 / 1909$ \\
\hline
\end{tabular}

\section{NOTES}

1 In this article I will use the term ecotype, although it also appears in older orthographical renderings as both oikotype and oicotype.

2 See von Sydow (1932: 321-344; 1934: 344-355).

3 It is clear however, as Gary Alan Fine (1992: 55) has argued, that these preconditions are not fixed and that not all folkloristic genres demand the same set of conditions. Moreover, I would argue that conditions such as 'isolation' are rarely applicable in the Modern Age due to the ubiquity of global technology and media networks.

4 Von Sydow (1948: 52) speaking of folk-tales as oicotypes states "The folk-tale he thus transmits is of an oicotype strange to the new place, and perhaps it will have to be immediately modified for the new circle of listeners."

5 The term community can refer to a linguistic, social, geographic, political, or racial community.

6 For a thought-provoking discussion of the ubiquity of biological metaphors in folklore scholarship, see Hafstein 2001.

7 The term morphology is somewhat misleading in that Propp was essentially proposing that, similar to formal syntax, folktales all share the same syntagmatic formations and sequence of functions (= signifcant actions performed by characters). See Barbara Johnstone (2001: 636).

8 Timothy Cochrane (1987: 38) mentions that Thompson's negative view of ecotypes as expressed in The Folktale (1946) preceded the publication of von Sydow's (1948) Selected Papers on Folklore (1948) and "many scholars were likely to be biased against the concept even before they had read it." It should be noted, however, that as discussed earlier von Sydow had published his initial contribution years earlier in Swedish in 1932 and in English in 1934.

9 The term urban legend is frequently used interchangeably with terms such as contemporary urban legend, contemporary legend, urban belief tale and modern legend (see Ellis 1983: 200).

10 See Cochrane (1987) and Hasan-Rokem (2016) for a comprehensive historiographic analysis of ecotypes.

11 Indeed, Hasan-Rokem (2016: 118) has pointed out that stable alterations in the structural element, as opposed to changes in description, content and style, are often viewed by scholars as a prerequisite for defining ecotypes.

12 A clear example of this is John Ashton's (2001: 57) study of the Webber series in the Newfoundland urban legend tradition, where he identifies the role of the folk group mentality on ecotypification. Likewise, Diane Goldstein (1996) demonstrates how the "Welcome to the World of AIDS" legend has been adapted to reflect the regional and cultural values of the Newfoundlanders, as well as a didactic message about the dangers of violating cultural norms. A unique approach to the transmission of ecotypes across borders is Fine's (1992) study of US contemporary legends in the New South Africa. His work shows that contemporary legends from the United States and Western Europe have been ecotypified in the New South Africa to fit with the specific socio-political context and that they are extremely reflective of the beliefs, attitudes and cultural values of the local population. In particular, his argument demonstrates the importance of both narration and audience reception in the performance of folklore. Hopkin (2003: 343), likewise, examines how aspects of popular culture in the province of Lorraine, France - particularly the dâyeman (a French rhyming couplet beginning with the phrase "I sell you...") - were modified 
in accordance with the social system, especially in areas where "geographical endogamy, concentration of population, and premarital conception" were most pronounced.

13 Henceforth, to avoid repetition of the Irish expression, the English translation will be used unless stated otherwise.

14 See Dundes 1962: 166, Kalčik 1975: 7 and Fine 1992: 55.

15 Please note that the corpus in Table 1 (Appendices) also includes a small number of sources from Australia.

16 It should be emphasised that the study will only use recorded appearances in literary texts and folkloristic sources in order to avoid speculation or conjecture about transmission in the absence of evidence.

17 Or 656 according to the Muslim calendar.

18 The tale does not have a title but for the purposes of this examination I will refer to it as Tied Stones and Loose Dogs.

19 It should be noted that some of the difficulties of translating the Persian text of Gulistann into English, especially from the point of view of grammatical differences, are discussed in Baleghizadeh and Sharifi 2010. The following translation is by Edward Rehatsek (1964): "A poet went to an amir of robbers and recited a panegyric but he ordered him to be divested of his robe. As the poor man was departing naked in the world, he was attacked from behind by dogs, whereon he intended to snatch up a stone but it was frozen to the ground and, being unable to do so, he exclaimed: "What whore-sons of men are these? They have let loose the dogs and have tied down the stones." The amir of the robbers who heard these words from his room laughed and said: "O philosopher, ask something from me." He replied: "I ask for my robe if thou wilt make me a present of it. We are satisfied of thy gift by departure. A man was hoping for the gifts of people. I hope no gift from thee. Do me no evil. The robber chief took pity upon him, ordered his robe to be restored to him and added to it a sheepskin jacket with some dirhems." [Emphasis mine.]

20 The schema has been has updated and developed in Labov 2013.

21 Samuel Taylor Coleridge in Omninia or Horae Otiosiores (Coleridge and Southey 1812) has famously described this as "a mental juxtaposition of incongruous ideas with the sensation, but without the sense, of connection." It is also defined as follows in the OED s.v. bull "A self-contradictory proposition; in mod. use, an expression containing a manifest contradiction in terms or involving a ludicrous inconsistency unperceived by the speaker".

22 The humour is derived from observant wit, which is an example of the Incongruity Theory of Humor. See Krikmann 2006: 27.

23 Sa'di states in the epilogue (G191) that he did not follow the conventional practice of borrowing material from fellow poets in his Gulistān.

24 Personal correspondence, November 19, 2014: “However, since Sa'di completed his Rose Garden (Gulistān in Persian) in the year 656 of the Muslim calendar, which corresponds to 1258 A.D., he must have either heard the story or adopted it from a literary source before that time. I very much doubt that this is a story that he made up."

25 Personal correspondence, November 20, 2014: "I remember having read the tale, and somehow I remember that in the version I read the stone was fast due to frost... I do not, however, find the tale or anything like it in my pre-Mongol Arabic sources."

26 This was an anonymous translation although it is frequently attributed to John Florio.

27 Whilst these positive impressions of the city are salient it should be noted, as pointed out in Raymond Williams' (1973: 1) seminal work The Country and the City, that "Powerful hostile associations have also developed: on the city as a place of noise, worldliness and ambition."

28 English Civil War (1642-1651).

29 It should be noted that much of the dissent was a result of rapid urban and suburban growth in the period as the period from the mid-16th century to the end of the 17th century had witnessed a population increase from 100,000 to 500,000 (Ward 1999: 24). For a discussion of 
the political divisions between city and suburban populations, see Pearl 1961: 43 and Rappaport 2002: 46, 62, 187, 231.

30 William Linneman (1974: 38) makes the case for many of the stereotypes actually being appreciated by Irish immigrants as comedy was a didactic means of showing them how not to behave in an urban environment. It is difficult to believe that this was the case, however, as shown in editorials castigating the unfettered immigration of Irish into the US and the attendant racial, social and economic strife that occurred as a result.

311851 Sangamo Journal / Illinois State Journal (March 11, 1851); Semiweekly Camden Journal (August 29, 1851).

32 The Ottawa Free Trader (January 15, 1870); The Bloomfield Times (February 15, 1870); Waynesboro Village Record (April 18, 1872).

33 The Aurora Borealis: Or Flashes of Wit; Calculated to Drown Dull Care and Eradicate the Blue Devils (Johnston 1831); The Columbia Democrat (Bloomsburg, PA 1846); Staunton Spectator (Staunton, VA 1867); Arizona Miner (Fort Whipple, AZ 1868); Wyoming Democrat (Tunkhannock, Wyoming Co., PA 1867); Jeffersonian Republican (Stroudsburg, PA 1868); and The Daily Phoenix (Columbia, SC 1868).

34 The first attested use of this variant tale is from The Examiner: Containing Political Essays on the Most Important Events of the Time; Public Laws and Official Documents (Gardenier 1814), but it also appeared in jest-books in 1830-1831 and in a variety of newspapers at various points throughout the century, particularly in 1841, 1846, 1867-1869, and 1886. Spectator, published as New-York Spectator, July 17, 1841; Jeffersonian Republican (Stroudsburg, PA), May 21, 1846; The Columbia Democrat (Bloomsburg, PA), May 30, 1846; Staunton Spectator (Staunton, VA), July 23, 1867; Arizona Miner (Fort Whipple, AZ), March 14, 1868; Daily Ohio Statesman (Columbus, OH), May 5, 1868; The Daily Phoenix (Columbia, SC), April 12, 1868; Memphis Daily Appeal (Memphis, TN), December 16, 1869; Perrysburg Journal (Perrysburg, Wood Co., OH), December 3, 1886.

35 This onomastic stereotype subsequently became the source of an entire sub-genre of jokes known as 'The Paddy Irishman joke'. See Roback 1944 for a list of nicknames featuring the 'Paddy' element, also McHale 1994 for a collection of Paddy Irishman jokes.

36 FGB s.v. anam.

37 María García-Bermejo Giner (2002) has examined regional dialects in 16th century jest books as a means of gathering information on the dialectal landscape in this early modern period. She argues that linguistic evidence from this period is a more accurate source of how regional dialects were represented than in subsequent centuries, where stereotypical representations became more conventionalised and where standardised language began to take root. She contends that although regional features are found, particularly in lexis and morphology, they are not used as frequently as is generally believed. This is particularly true of the Irish stereotype, which is used much less in characterisations than that of the Welsh or the Scot. For a more extensive analysis of the use of dialectal language in literary works in the 14th and 15th centuries and earlier, see Blake 1981.

38 FGB s.v. arú.

39 [1] The verb form 'met' is found in the following sources: The Huddersfield Chronicle and West Yorkshire Advertiser (West Yorkshire, England 1851); The Northern Star and National Trades' Journal (Leeds 1851); The Preston Guardian (Preston 1851); The Leicester Chronicle: Or, Commercial and Agricultural Advertiser (Leicester 1851); Diprose's Funny Book (London 1854); Cheshire Observer and General Advertiser: for Cheshire and North Wales (Chester 1854); Aberystwyth Observer (Aberystwyth, Wales 1875); Cambrian (Aberystwyth, Wales 1883). [2] The verb form 'startled' is found in the following sources: The Bristol Mercury (Bristol 1869); The Hampshire Advertiser (Southampton 1869); Cheshire Observer and Chester, Birkenhead, Crewe and North Wales Times (Chester 1870); The Newcastle Courant (Newcastle-Upon-Tyne 1870); The Ottawa Free Trader (Ottawa, IL 1870); The Bloomfield Times (Bloomfield, NJ 1870). [3] The verb form 'accosted' is found in the fol- 
lowing sources: Sangamo Journal [Illinois State Journal] (Springfield, IL 1851); Semiweekly Camden Journal (Camden, SC 1851); The Bradford Observer (Bradford 1862); The Book of Blunders: Comprising Hibernicisms, Bulls that are not Irish and Typographic Errors (Philadelphia, PA 1871); Waynesboro Village Record (Waynesboro, PA 1872).

40 These examples are footnoted in the source text but I thought it prudent to include them in the main text here for the sake of clarity.

41 See also, for example, the Nashville Union and Dispatch in 1867: "He spoke of the Loyal League and the five L's: Lincoln, Law, Liberty, Loyal, League. Speaking of liberty in Tennessee, he said that it reminded him of an Irishman who came to this country for liberty, and was attacked by a dog and the stones were frozen in the road, so that he could not raise them to keep the dog away. The dog attacked him, and the owner told him to get out. "Get out," said he, "I come here for liberty, but it's a quare liberty you have when the dogs are loose and the stones tied fast!" The Radical dogs are loose and your votes are tied fast."

42 "The term blason populaire (lit. 'popular emblem') denotes an ethnic and cultural verbal stereotype about a folk group or the inhabitants of a particular region" (Gryzbek 1994: 19). For a discussion of the blason populaires in Irish proverbial material, see Mac Coinnigh 2013.

43 "I come from County Limerick and there's a town there, Ballyneety (Baile an Fhaoitigh), Whitestown it means actually, and there was a beggarman passing through there one day... and a dog ran out, a savage dog and he bent down to pick up a stone to keep the dog away from him. But the stone was stuck to the ground and so the dog went and tore the arse out of the poor man. And all he could say was: 'Is olc an baile, Baile an Fhaoitigh, go bhfuil clocha ceangailte ann agus madrai scaoilte!' 'Ballyneety is a bad place because the stones are tied there and the dogs are loose!'” (Ó hÓgáin 2004)

44 "Said the beggar: he was heading towards a house on a winter's day and dogs were set on him to chase him away; when he attempted to grab a stone to throw at them, they were all frozen to the ground." [Translation mine.]

45 See comments by Judge Hardiman in O'Callaghan v. Judge Alan Mahon \& Ors [2005] IESC 9.

46 See Hogan and Gwynn Morgan 1998: 541: “The audi alteram partem rule embraces two types of obligation (although there is a substantial overlap and nothing turns on the distinction). First, the person to be affected by the decision must have notice of it, that is, he must be alerted to it and be given details. Secondly, he must be allowed appropriate facilities to make the best possible case in reply."

47 Most notably State (Healy) v Donoghue [1976] IR 325; Donnelly v Ireland [1998] 1 IR 321; Maguire vs Ardagh [2002] IESC 21, [2002] 1 IR 385 and O'Callaghan v Judge Alan Mahon \& Ors [2005] IESC 9. It has also been frequently referenced in legal tribunals and commissions such as The Law Reform Commission (An Coimisiún um Athchóiriú an Dlí) Consultation Paper on Child Sexual Abuse (August 1989).

48 For example, Irish Parliament records show the phrase was used by Prof. John M. Kelly, Minister for Trade, Commerce, and Tourism in a debate in 1978. "There is an old Irish proverb which states: 'Clocha ceangailte agus madraí scaoilte' - 'stones tied down and dogs on the loose'; in other words, it is all right for Deputy Haughey to raise points about there being no glimmer of hope in the budget statement but it is not all right for me to reply to them." (Financial Resolutions 1932).

49 (1) The first source is in Wikileaks documents relating to Pakistan, where it is used with direct reference to Sa'di to demonstrate the concept of 'unfairness' - where one side is permitted to attack another without retort to defense. "Exasperated he said, "Een Che haramzada mardumaanand, saggaan ra kushaada-and, 'o' sing ra basta" (how wantonly evil these folk are, they have tied the stones and unleashed the dogs). This is exactly how things are in Balochistan: the people are disempowered and crushed while the chosen 'patriotic elements' and the establishment are unleashed" (Talpur 2011). (2) The second main source is in Russian language tales (over 20 online 
sources), the earliest of which is from a journal Russkiye zapiski (previously, Russkoye bogatstvo), published in St Petersburg in 1916. The story by the author Fyodor Dmitriyevich Kryukov is called "Group B (Silhouettes)" and features as a reminiscence of one of characters about the anecdote. In most of the other online examples, however, the core meaning of injustice is used as the basis for a 'toast for justice', particularly in regions of Caucasus. The most common example is as "A traveler was going along the village once. Dogs attacked him. He decided to use stones to strike them but the stones had been frozen to the ground - winter was coming - God! Where is justice - dogs are unchained and stones are tied! - cried the traveler. Let us drink for justice." I would like to thank Nicíota Koptev for providing a English translation.

50 As Bo Almqvist (1975: 20) has noted: "The question of the interplay of folklore and 'booklore' is very intricate in Ireland. It seems likely that the written or printed word has played a more important role here than in other countries."

51 Dégh (1994: 20) is quite emphatic in this regard: "There can be no question that the folklore process, the creation and transmission of [...] types and variants results from the constant interdependence between oral and written formulations."

\section{SOURCES}

National Folklore Collection. The Schools' Collection:

NFCS 0656:005; Píaras de Bhál (73), Knocknaree, Co. Waterford. Collector: Séamas Ó Maoldhomhnaigh, Glenanore, Glennanore, Co. Waterford, 1934. Teacher: Séamas Ó Maoldhomhnaigh. https://www.duchas.ie/en/cbes/5162153/5159235/5180400 (accessed July 10, 2018).

NFCS 1034:160; Danny Meehan (-), Donegal, Co. Donegal. Collector: Séamus Mag Shamhráin, Aodh Rua, Dún nan Gall, 1938. Teacher: Séamus Mag Shamhráin. https://www.duchas.ie/en/ cbes/4428278/4391033 (accessed July 10, 2018).

The following cases relate to The Supreme Court of Ireland and are reported in The Irish Reports

[IR]. The Irish Reports are available in hard copy and online via the Justis and JustCite search engines (http://www.irishreports.ie/publications/justis-justcite.htm):

Donnelly v Ireland [1998] 1 IR 321

Maguire vs Ardagh [2002] IESC 21, [2002] 1 IR 385

O'Callaghan $v$ Judge Alan Mahon \& Ors [2005] IESC 9

Re Haughey [1971] IR 217

State (Healy) v Donoghue [1976] IR 325

\section{REFERENCES}

Abrahams, Roger. 1963. Folklore in Culture: Notes Toward an Analytic Method. - Texas Studies in Literature and Language 5 (1): 98-110.

Abrahams, Roger. 1964. Deep Down in the Jungle: Black American Folklore from the Streets of Philadelphia. Hatboro, PA: Folklore Associates.

Almqvist, Bo. 1975. The Fisherman in Heaven. - Hereditas: Essays and Studies presented to Professor Séamus Ó Duilearga, former Honorary Director of the Irish Folklore Commission, editor of Béaloideas, 1927-1973, Patron of the Folklore of Ireland Society, edited by Bo Almqvist, Breandán Mac Aodha and Gearóid Mac Eoin. Dublin: Folklore of Ireland Society, 1-55.

Anon. 1620. The Decameron. London: Iaggard.

Anon. 1798. The Weekly Magazine of Original Essays, Fugitive Pieces, and Interesting Intelligence. Philadelphia, PA: J. Watters \& Co. 
Anon. 1897. Giotaidhe ó Chonntae Phortláirge. - Irisleabhar na Gaedhilge 7: 151.

Ashton, John. 2001. Ecotypes, Etiology and Contemporary Legend: The 'Webber' Cycle in Western Newfoundland. - Contemporary Legend 4: 48-60.

Baleghizadeh, Sasan and Ahmad Sharifi. 2010. Explicitation of Implicit Logical Links in PersianEnglish Translation. - Translation \& Interpreting 2 (2): 57-65.

Ballard, Linda-May. 1983. The Formulation of the Oicotype: A Case Study. - Fabula 24 (3): 233245. DOI: https://doi.org/10.1515/fabl.1983.24.3-4.233.

Barber, Karin. 2007. The Anthropology of Texts, Persons and Publics: Oraland Written Culture in Africa and Beyond. Cambridge: Cambridge UniversityPress. DOI: https://doi.org/10.1017/ CBO9780511619656.

Beyer, Jürgen. 2011. Are Folklorists Studying the Tales of the Folk? - Folklore 122 (1): 35-54. DOI: https://doi.org/10.1080/0015587X.2011.537132.

Blake, Norman F. 1981. Non-Standard Language in English Literature. London: André Deutsch.

Boerth, Robert. 2000. Review. Travels through Stuart Britain: The Adventures of John Taylor, the Water Poet by John Chandler. - Sixteenth Century Journal 31 (3): 915-916. DOI: https://doi. org/10.2307/2671156.

Bošković-Stulli, Maja. 1966. Regional Variations in Folktales. - Journal of the Folklore Institute 3 (3): 299-314. DOI: https://doi.org/10.2307/3813803.

Bourgeois, Maurice. 1913. John Millington Synge and the Irish Theatre. London: Constable \& Company Ltd.

Bracciolini, Poggio. 1470. Poggii Florentini ... Facetiarum Liber. Rome: Georg Lauer.

Briggs, Charles L. 1993. Metadiscursive Practices and Scholarly Authority in Folkloristics. - The Journal of American Folklore 106 (422): 387-434. DOI: https://doi.org/10.2307/541905.

Brunvand, Jan Harold. 1974. Folklore: A Study and Research Guide. New York, NY: St. Martin's Press.

Brunvand, Jan Harold. 1981. The Vanishing Hitchhiker: American Urban Legends and Their Meanings. New York, NY: W. W. Norton and Company.

Capp, Bernard. 1994. John Taylor the Water-Poet: 1578-1653. Oxford: Clarendon Press. DOI: https:// doi.org/10.1093/acprof:oso/9780198203759.001.0001.

Capp, Bernard. 2004. Taylor, John [called the Water Poet] (1578-1653). DOI: https://doi.org/10.1093/ ref:odnb/27044.

Carroll Bombaugh, Charles. 1871. The Book of Blunders. Comprising Hibernicisms, Bulls that are not Irish and Typographic Errors. Philadelphia, PA: Evans, Stoddart and Co.

Castiglione, Baldassarre. 1528. Il Libro Del Cortegiano Del Conte Baldesar Castiglione. Venetiis.

Chandler, John H. 1999. Travels through Stuart Britain: The Adventures of John Taylor, the Water Poet. Stroud: Sutton.

Cochrane, Timothy. 1987. The Concept of Ecotypes in American Folklore. - Journal of Folklore Research 24 (1): 33-55.

Coleridge, Samuel Taylor and Robert Southey. 1812. Omniana, or Horae Otiosiores. London: Longman.

Cunningham, Keith Kermit. 1976. A Study of the Southern Folk Song Style Area Sweetheart Murder Ballad: The Search for an Oicoclass. A PhD Thesis. Indiana University.

Dégh, Linda. 1961. Die schöpferische Tätigkeit des Erzählers. - Internationaler Kongreß der Volkserzählungsforscher in Kiel und Kopenhagen: Vorträge und Referate, edited by Kurt Ranke. Berlin: De Gruyter, 63-73.

Dégh, Linda. 1972. Folk Narrative. - Folklore and Folklife: An Introduction, edited by Richard M. Dorson. Chicago, IL: University of Chicago Press, 53-83.

Dégh, Linda. 1994. American Folklore and the Mass Media. Bloomington, IN: Indiana University Press. 
De hÍde, Dubglas, 2013. Lia Fáil: Irisleabar Gaedilge Ollsgoile na hÉireann / ar n-a ċur i n-eagar leis an gCraoibin (Dubglas de híde). Dublin: Ollscoil na hÉireann.

Dorson, Richard M. 1956. Negro Folktales in Michigan. Cambridge, MA: Harvard University Press. DOI: https://doi.org/10.4159/harvard.9780674330252.

Dundes, Alan. 1962. The Binary Structure of 'Unsuccessful Repetition' in Lithuanian Folk Tales. Western Folklore 21 (3): 165-174. DOI: https://doi.org/10.2307/1496955.

du Ryer, André. 1634. Gulistan ou l'Empire des Roses. Paris: de Sommaville.

Earls, Brian. 1988. Bulls, Blunders and Bloothers: An Examination of the Irish Bull. - Béaloideas 56: 1-92. DOI: https://doi.org/10.2307/20522309.

Ellis, Bill. 1983. De Legendis Urbis: Modern Legends in Ancient Rome. - The Journal of American Folklore 96 (380): 200-208. DOI: https://doi.org/10.2307/540293.

European Convention on Human Rights = European Convention for the Protection of Human Rights and Fundamental Freedoms, as amended by Protocols Nos. 11 and 14. 4 November 1950. Council of Europe. https://www.echr.coe.int/Documents/Convention_ENG.pdf (accessed March 29, 2019).

Financial Resolutions 1982 = Dáil Éireann debate, Financial Resolutions, 1982: Financial Resolution No. 1: Excise-Beer, Wednesday, 27 January 1982. https://www.oireachtas.ie/en/debates/ debate/dail/1982-01-27/24/ (accessed April 1, 2019).

Fine, Gary Alan. 1987. Welcome to the World of AIDS: Fantasies of Female Revenge. - Western Folklore 46 (3): 192-197. DOI: https://doi.org/10.2307/1499525.

Fine, Gary Alan. 1992. Rumors of Apartheid: The Ecotypification of Contemporary Legends in the New South Africa. - Journal of Folklore Research 29 (1): 53-71.

FGB = Ó Dónaill, Niall. 1977. Foclóir Gaeilge-Béarla. Baile Átha Cliath: Oifig an tSoláthair. http:// www.teanglann.ie/ga/ (accessed March 3, 2019).

Foster, John Wilson. 1969. A Descriptive Nomenclature for the Study of lore, Part II: The Evolutionary Model. - Western Folklore 28 (2): 101-111. DOI: https://doi.org/10.2307/1498507.

Friedman, Albert. 1974. 'When Adam Delved...': Contexts of an Historic Proverb. - Harvard English Studies 4: 213-230.

Fritze, Ronald H. and William B. Robison, eds. 1996. Historical Dictionary of Stuart England, 16031689. Westport, CT: Greenwood Publishing.

García-Bermejo Giner, María F. 2002. Regional Dialects in Sixteenth-Century Jest-Books. - Sederi 12: 209-218.

Gardenier, Barent, ed. 1814. The Examiner: Containing Political Essays on the Most Important Events of the Time; Public Laws and Official Documents 2. New York, NY: Published by the editor, No. 34 Cedar Street.

Gentius, Georgius. 1651. Musladini Sadi Rosarium Politicum; Sive Amœnum Sortis Humanæ Theatrum De Persico in Latinum Versum, Necessariisque Notis Illustratum a G. Gentio. Amstelædami.

Gilbert, B. C. 1847. Atwater, Portage co., July 12 '47. - Anti-Slavery Bugle, July 23.

Gladwin, Francis. 1806. The Gûlistân of Sâdy. With Notes and References to the English Translation. Calcutta: Hindoostanee Press.

Goldstein, Diane E. 1996. Welcome to the Mainland, Welcome to the World of AIDS: Cultural Variability, Localization and Contemporary Legend. - Contemporary Legend: A Reader, edited by Gillian Bennett and Paul Smith. New York, NY: Garland Publishing, 209-224.

Grzybek, Peter. 1994. Blason populaire. - Simple Forms. An Encyclopaedia of Simple Text-types in Lore and Literature, edited by Walter A. Koch. Bochum: Brockmeyer, 19-25.

Hafstein, Valdimar. 2001. Biological Metaphors in Folklore Theory: An Essay in the History of Ideas. - Arv. Nordic Yearbook of Folklore 57: 7-32.

Hasan-Rokem, Galit. 2000. Web of Life: Folklore and Midrash in Rabbinic Literature. Stanford, CA: Stanford University Press. 
Hasan-Rokem, Galit. 2003. Tales of the Neighborhood: Jewish Narrative Dialogues in Late Antiquity. Taubman Lectures on Jewish Civilisation. Berkeley, CA: University of California Press.

Hasan-Rokem, Galit. 2016. Ecotypes: Theory of the Lived and Narrated Experience. - Narrative Culture 3 (1): 110-137. DOI: https://doi.org/10.13110/narrcult.3.1.0110.

Hazlitt, William Carew. 1887. A Hundred Merry Tales: The Earliest English Jest-book. Now First Reproduced in Photo-lithography from the Unique Copy of 1526 in the Royal Library at Göttingen. With an Introduction, Notes, and Glossarial Index by W. Carew Hazlitt. London: J. W. Jarvis \& Son.

Higgins, Michael D. 2012. Remarks at a Reception for Delegates at Law Commissions Meeting. - President of Ireland. http://www.president.ie/en/media-library/speeches/remarks-at-a-reception-for-delegates-at-law-commissions-meeting (accessed June 19, 2018).

Hogan, Gerard and David Gwynn Morgan. 1998. Administrative Law in Ireland. Dublin: Thomson Round Hall.

Hopkin, David M. 2003. Love Riddles, Couple Formation, and Local Identity in Eastern France. Journal of Family History 28 (3): 339-363. DOI: https://doi.org/10.1177/0363199003256014.

Hopkin, David M. 2016. The Ecotype, or a Modest Proposal to Reconnect Cultural and Social History. - Exploring Cultural History: Essays in Honour of Peter Burke, edited by Melissa Calaresu, Joan-Pau Rubies, and Filippo de Vivo. London: Routledge, 31-54.

Järviö-Nieminen, Iris. 1959. Suomalaiset Sanomukset: Finnish Wellerisms. Suomalaisen Kirjallisuuden Seuran toimituksia 259. Helsinki: Suomalaisen Kirjallisuuden Seura.

Johnston, David C. 1830. The Galaxy of Wit: Or, Laughing Philosopher, Being a Collection of Choice Anecdotes, Many of which Originated in Or about "The Literary Emporium." Boston, MA: Stereotyped by J. Reed.

Johnston, David C. 1831. The Aurora Borealis: Or Flashes of Wit; Calculated to Drown Dull Care and Eradicate the Blue Devils. Boston, MA: J. H. A. Frost.

Johnstone, Barbara. 2001. Discourse Analysis and Narrative. - The Handbook of Discourse Analysis, edited by Deborah Schiffrin, Deborah Tannen and Heidi E. Hamilton. Oxford: Blackwell Publishers, 635-649.

Kalcik, Susan. 1975. “... Like Ann's Gynecologist or the Time I Was Almost Raped”: Personal Narratives in Women's Rap Groups. - The Journal of American Folklore 88 (347): 3-11. DOI: https:// doi.org/10.2307/539181.

Klapp, Orrin E. 1949. The Fool as a Social Type. - American Journal of Sociology 55 (2.1): 157-162.

Knobel, Dale T. 1981. A Vocabulary of Ethnic Perception: Content Analysis of the American Stage Irishman, 1820-1860. - Journal of American Studies 15 (1): 45-71. DOI: https://doi.org/10.1017/ S0021875800005107.

Krikmann, Arvo. 2006. Contemporary Linguistic Theories of Humour. - Folklore 33: 27-58. https:// www.folklore.ee/folklore/vol33/kriku.pdf (accessed February 27, 2019).

Kunstmann, John G. 1939. The Bird that Fouls Its Nest. - Southern Folklore Quarterly 3: 75-91.

Labov, William and Waletzky, Joshua. 1967. Narrative Analysis. Seattle, WA: University of Washington Press.

Labov, William. 2013. The Language of Life and Death. Cambridge: Cambridge University Press. DOI: https://doi.org/10.1017/CBO9781139519632.

The Law Reform Commission = An Coimisiún um Athchóiriú an Dlí. Consultation Paper on Child Sexual Abuse. 1989. Ireland, The Law Reform Commission. https://www.lawreform.ie/_fileupload/consultation\%20papers/cpChildSexAbuse.htm (accessed April 1, 2019).

Linneman, William R. 1974. Immigrant Stereotypes: 1880-1900. - Studies in American Humor 1 (1): 28-39.

Löfgren, Orvar. 1976. Peasant Ecotypes: Problems in the Comparative Study of Ecological Adaptation. - Ethnologia Scandinavica 6: 100-115.

Löfgren, Orvar. 1980. Historical Perspectives on Scandinavian Peasantries. - Annual Review of Anthropology 9: 187-215. DOI: https://doi.org/10.1146/annurev.an.09.100180.001155. 
Mac Coinnigh, Marcas. 2013. The Blason Populaire: Slurs and Stereotypes in Irish Proverbial Material. - Folklore 124 (2): 157-177. DOI: https://doi.org/10.1080/0015587X.2013.778445.

MacHale, Des. 1994. Paddy the Englishman, Paddy the Irishman, and Paddy the Scotsman Jokes. Cork: Mercier Press.

Mac Síthigh, Tomás. 1940. Cortha Cainnte na Gaedhilge. Baile Átha Cliath: Preas Náisiúnta.

Marshall, John J. 1931. Popular Rhymes and Sayings of Ireland. Dungannon: Tyrone Printing Company.

Massé, Henri. 1919. Essai sur le poète Saadi 1-2. Paris: Librairie Paul Geuthner.

Mieder, Wolfgang and Wayland D. Hand. 1991. '(Don't) Throw the Baby out with the Bath Water': The Americanization of a German Proverb and Proverbial Expression. - Western Folklore 50 (4): 361-400. DOI: https://doi.org/10.2307/1499674.

Mieder, Wolfgang. 1996. 'No Tickee, No Washee.' - Western Folklore 55: 1-40. DOI: https://doi. org/10.2307/1500147.

Narváez, Peter. 2002. "I Think I Wrote a Folksong": Popularity and Regional Vernacular Anthems. Journal of American Folklore 115 (456): 269-282. DOI: https://doi.org/10.2307/4129223.

NFC 2018 = National Folklore Collection and its collections. - Dúchas.ie. https://www.duchas.ie/ en/info/cbe (accessed July 10, 2018).

Ó Coileáin, Seán. 1977. Oral or Literary? Some Strands of the Argument. - Studia Hibernica 17/18: 7-35.

O'Daly, John. 1876. The Irish Language Miscellany: Being a Selection of Poems by the Munster Bards of the Last Century. Collected and edited by John O'Daly. Dublin: J. O'Daly.

Ó hAodha, Nioclás. 1970. Foclóir agus Nótaí do 'Mo Scéal Féin' a scríobh an tAthair Peadar Ó Laoghaire. Baile Átha Cliath: Albert Folens.

Ó hÓgáin, Dáithí. 2004. Dáithí Ó hÓgáin on Storytelling. - Storytellers of Ireland. https://www.storytellersofireland.org/documents/daithi-o-hogain-on-storytelling/ (accessed June 19, 2018).

O'Leary, Peter. 1931. Aodh Ruadh (Cuid II). Baile Átha Cliath: Brún \& Ó Nualláin.

Ó Máille, Tomás S. 1948. Sean-fhocla Chonnacht I. Baile Átha Cliath: Oifig an tSoláthair.

Ó Máille, Tomás S. 1952. Sean-fhocla Chonnacht II. Baile Átha Cliath: Oifig an tSoláthair.

Ó Riain, Liam. 1952. Lán-chúrsa na Gaeilge. Baile Átha Cliath: Ó Fallúin.

Ó Siochfhradha, Pádraig. 1926. Seanfhocail na Muimhneach. Cork: Cló-chualacht Seandúna. [Reprinted in 1984 with additions by Pádraig Ua Maoileoin. Dublin: An Gúm.]

Ochsenbach, Friedrich. 1636. Gulistan, das ist Königlicher Rosengart. Tübingen: Bey Philibert Brunn. OED = Oxford English Dictionary online. http://www.oed.com (accessed June 19, 2018).

Pearl, Valerie. 1961. London and the Outbreak of the Puritan Revolution: City Government and National Politics, 1625-43. London: Oxford University Press.

Piirainen, Elisabeth. 2012. Widespread Idioms in Europe and Beyond: Toward a Lexicon of Common Figurative Units. New York, NY: Peter Lang. DOI: https://doi.org/10.3726/978-1-4539-0845-7.

Piirainen, Elisabeth. 2016a. Lexicon of Common Figurative Units: Widespread Idioms in Europe and Beyond II. In cooperation with József Attila Balázsi. New York, NY: Peter Lang. DOI: https:// doi.org/10.3726/b10457.

Piirainen, Elisabeth. 2016b. Phraseologie und figuratives Lexikon: Kleine Schriften. Tübingen: Stauffenburg.

Piirainen, Elisabeth and Dmitrij Dobrovol'skij. 2005. Figurative Language: Cross-cultural and Crosslinguistic Perspectives. Amsterdam: Elsevier.

Propp, Vladimir. 1958. Morphology of the Folktale, edited by Svatava Pirkova-Jakobson, translated by Laurence Scott. Bloomington, IN: Indiana University Research Center in Anthropology.

Rappaport, Steve. 2002. Worlds Within Worlds: Structures of Life in Sixteenth-Century London. Cambridge: Cambridge University Press.

Rehatsek, Edward. 1964. The Gulistan or Rose Garden of Sa'di. London: George Allen \& Unwin Ltd. 
Reinke-Williams, Tim. 2009. Misogyny, Jest-Books and Male Youth Culture in Seventeenth Century England. - Gender \& History 21 (2): 324-339. DOI: https://doi.org/10.1111/j.14680424.2009.01551.x.

Roback, Abraham A. 1944. A Dictionary of International Slurs. Cambridge, MA: Sci-Art.

Roberts, Warren E. 1953. Aarne-Thompson Type 480 in World Tradition: A Comparative Folktale Study. A PhD Thesis. Indiana University.

Roberts, Warren E. 1966. The Black and White Bride, Aa-Th 403, in Scandinavia. - Fabula 8 (1): 64-92. DOI: https://doi.org/10.1515/fabl.1966.8.1.64.

Ross, James. 1823. The Gulistan, or Flower-Garden of Shaikh Sadî of Shiraz: translated into English by James Ross, Esq. London: J. M. Richardson.

Said, Edward. 1978. Orientalism: Western Representations of the Orient. New York, NY: Pantheon.

Sulivan, Stephen. 1774. Select Fables from Gulistan or the Bed of Roses. Translated from the Original Persian of Sadi by Stephen Sulivan, Esq. London: J. Ridley, St. James's Street.

von Sydow, Carl Wilhelm. 1932. Om traditionspridning. - Scandia 5 (2): 321-344.

von Sydow, Carl Wilhelm. 1934. Geography and Folk-Tale Oicotypes. - Béaloideas 4: 344-355. DOI: https://doi.org/10.2307/20521833.

von Sydow, Carl Wilhelm, ed. 1948. Selected Papers on Folklore. Copenhagen: Rosenkilde and Bagger.

Talpur, Mir Mohammad Ali. 2011. Saggaan ra kushaada-and, o sing ra basta. - Daily Times, July 30, 2011. https://dailytimes.com.pk/111223/saggaan-ra-kushaada-and-o-sing-ra-basta/ (accessed July 10, 2018).

Taylor, John. 1626. Wit and Mirth, chargeably collected out of Tavernes, Ordinaries, Innes, Bowling Greenes, and Allyes, Alehouse, Tobacco shops, Highwayes and Water-passages. Made up and fashioned into Clinches, Bulls, Quirkes, Yerkes, Quips, and Jerkes etc. By John Taylor, Water-Poet. London: James Boler.

Thompson, Stith. 1968. Hypothetical Forms in Folktale Study. - Volkiiberlieferung: Festschrift für Kurt Ranke, edited by Fritz Harkort, Karel C. Peeter and Robert Wildhaber. Göttingen: Otto Swartz, 369-372.

Uí Bhraonáin, Donla, ed. 2010. Seanfhocla Chonnacht. 2nd edn. Dublin: Cois Life.

Utley, Francis Lee. 1975. The Urban and the Rural Jest (With an Excursus on the Shaggy Dog). Hereditas: Essays and Studies presented to Professor Séamus Ó Duilearga, Former Honorary Director of the Irish Folklore Commission, Editor of Béaloideas, 1927-1973, Patron of the Folklore of Ireland Society, edited by Bo Almqvist, Breandán Mac Aodha and Gearóid Mac Eoin. Dublin: Folklore of Ireland Society, 344-357.

Waage, Frederick. O. 1973. John Taylor (1577-1654) and Jacobean Popular Culture. - The Journal of Popular Culture 7 (3): 589-601.

Ward, Joseph P. 1999. Imagining the Metropolis in Elizabethan and Stuart London. - The Country and the City Revisited: England and the Politics of Culture 1550-1850, edited by Gerarld Maclean, Donna Landry and Joseph P. Ward. Cambridge: Cambridge University Press, 24-40.

Williams, Raymond. 1973. The Country and the City. New York, NY: Oxford University Press.

Wolf, Eric R. 1966. Peasants. Englewood Cliffs, NJ: Prentice-Hall.

Woodbridge, Linda. 2003. Jest Books, the Literature of Roguery, and the Vagrant Poor in Renaissance England. - English Literary Renaissance 33 (2): 201-210.

Zall, Paul M. 1980. The Old Age of American Jestbooks. - Early American Literature 15 (1): 3-13. 